Original Article

\title{
Trophic relationships among three species of ornamental fish from the region of Lake Amanã, Amazon
}

\author{
Relações tróficas entre três espécies de peixes ornamentais da região do lago de \\ Amanã, Amazonas \\ S. M. Santos a (iD , P. H. R. Arideb (iD , J. Pantoja-Limac (iD , A. T. Oliveirab* (iD) and J. A. S. Zuanon ${ }^{\mathrm{d}}$ (iD) \\ aInstituto Federal de Educação Ciência e Tecnologia do Amazonas - IFAM, Campus Manaus Zona Leste CMZL, Manaus, AM, Brasil \\ 'Instituto Federal de Educação, Ciência e Tecnologia do Amazonas - IFAM, Campus Manaus Centro - CMC, Manaus, AM, Brasil \\ 'Instituto Federal de Educação Ciência e Tecnologia do Amazonas - IFAM, Campus Presidente Figueiredo - CPRF, Presidente Figueiredo, AM, \\ Brasil \\ 'Instituto Nacional de Pesquisas da Amazônia - INPA, Coordenação de Biodiversidade, Manaus, AM, Brasil
}

\begin{abstract}
The present study objectified to evaluate the trophic relationships and the possible aggressive mimicry involving Carnegiella strigata, Carnegiella marthae and Gnathocharax steindachneri, in lowland forest streams. Samplings occurred in November 2002, March and August 2003 in Amanã Sustainable Development Reserve (ASDR). The total of 943 fish was caught, being $79.43 \%$ of C. marthae, 3.18\% of C. strigata and $17.39 \%$ of G. steindachneri. Stomach contents, degree of stomach repletion, relative volume and frequency of occurrence of food items were evaluated. Thirteen food items were identified, and the presence of terrestrial and aquatic insects indicates the high dependence of these species and the flooded forest. Low feeding overlap was observed between Carnegiella strigata and C. marthae compared to Gnathocharax steindachneri. However, the overlap between the two Carnegiella species was relatively high, which could explain the low frequency of syntopic occurrence among these species, suggesting a possible case of competitive exclusion.
\end{abstract}

Keywords: food, freshwater fish, mimic, diet.

\section{Resumo}

Este estudo teve como objetivo analisar as relações tróficas e a possível existência de uma relação de mimetismo agressivo envolvendo Carnegiella strigata, Carnegiella marthae e Gnathocharax steindachneri, em igarapés de terra firme. As coletas ocorreram em novembro de 2002, março e agosto de 2003 e foram realizadas na Reserva de Desenvolvimento Sustentável de Amanã (RDSA). Foram capturados 943 peixes, onde $C$. marthae representou $79,43 \%$, C. strigata 3,18\% e G. steindachneri $17,39 \%$. Foram analisados os conteúdos estomacais e verificados grau de repleção, volume relativo e frequência de ocorrência dos alimentos. Foram identificados 13 itens alimentares, onde insetos terrestres e aquáticos denotaram alto grau de dependência destas espécies em relação à floresta alagada. Ocorreu baixa sobreposição alimentar das espécies Carnegiella strigata e $C$. marthae em relação a Gnathocharax steindachneri. Entretanto, a sobreposição entre as duas espécies de Carnegiella foi relativamente alta, o que poderia explicar a baixa frequência de ocorrência sintópica entre essas espécies, sugerindo um possível caso de exclusão competitiva.
\end{abstract}

Palavras-chave: alimentação, peixe de água doce, mímico, dieta.

\section{Introduction}

In the Amazon ichthyofauna, the species of the Gasteropelecidae family, Carnegiella strigata (Günther, 1864) and Carnegiella marthae (Myers, 1927), which are popularly known as butterfly fish, stand out due to the distinctive body shape and are normally commercialized as ornamental (Anjos et al., 2009; Ladislau et al., 2019). This species abundant especially in flooded areas in rivers of dark and white water of Amazon, including lowland forest streams of Central Amazon (Barros et al., 2011; Queiroz et al., 2013). They have as main characteristics, the small body (are small) and the narrow ventral region and an expanded, fan-shaped pectoral waist, consisting of fused and expanded coracoids, pectoral fin elongated and positioned to the top and the side. Such modifications allow small jumps above the water surface (Wiest, 1995; Weitzman and Palmer, 1996). The geographic distribution of C. marthae comprises Venezuela and Brazil and C. strigata

*e-mail: adriano.oliveira@ifam.edu.br

Accepted: January 2, 2020 - Accepted: August 20, 2020

This is an Open Access article distributed under the terms of the Creative Commons Attribution License, which permits unrestricted use, distribution, and reproduction in any medium, provided the original work is properly cited. 
naturally occurs in Colombia, Guyana, Peru, Surinam and Brazil (Weitzman and Palmer, 2003).

Another species that is confused and also traded with butterfly fish is the species Gnathocharax steindachneri (Fowler, 1913) from Characidae family, with occurrence restricted to northern South America including Brazil, Guyana and Venezuela, also occurs in lowland forest streams and in rivers of white water (Barros et al., 2011; Queiroz et al., 2013) and dark water (Montag et al., 2008). This species presents morphological characteristics similar to the species of the genus Carnegiella, with expanded pectoral waist and long pectoral fins, although not as modified as in butterfly fish (Weitzman and Palmer, 1996). G. steindachneri are found and captured together the shoals of Carnegiella spp and are usually erroneously sold as butterfly fish in the national and international market of ornamental fish due to their morphological similarities.

The morphological similarity between the species described, besides the fact they are usually found and collected together, indicate that the association of these species should not be fortuitous, but may be related to the occupation of similar trophic niches. The top mouth of Carnegiella spp. and the powerful pectoral fins should probably provide fast and efficient capture of feed that fall on the water surface, from the riparian forest (Sabino and Zuanon, 1998) and can be associated to a non-piscivorous diet, while G. steindachneri have upward largemouth used to prey insects on the water surface (Queiroz et al., 2013).

Study by Pereira et al., (2011) reported the possibility of protective mimicry involving species of the genus Haemulon with similar morphology forming a single shoal, and this grouping has a protective function. However, Sazima et al., (2005) reported an aggressive mimicry between two species (Cephalopholis fulva and Chromis multilineata) with similarly sized and coloured that associated is able to approach unaware prey which made the disguise successful.

The reasons that generate associations among fish species study are unknown, but may represent factors such as interspecific feeding associations, partial sharing of habitats (Pacheco and da Silva, 2009) and trophic relationships (Novakowski et al., 2007; Oliveira et al., 2020), however it is common fish species presenting similar feeding behavior and living in the same space, however, these usually have different foraging methods, suggesting that behavioral differences are essential to species coexistence (Mise et al., 2013). However, aggressive interactions are common among fish of the same guild and individuals of each species can obtain advantages in feed efficiency over other individuals from other species of the same trophic guild (Menegatti et al., 2003).

The studied species are economically important a ornamental species, being collected for the subsistence of riverside dwellers in the region of the middle Rio Negro (Chao, 1998, 2001; Ladislau et al., 2019), and are representative (1-4\%) in the collections of these piabeiros. The morphological similarity between Gnathocharax and Carnegiella, associated with the fact that they are observed and collected together in nature, indicates that the association of these species should not be casual, but associated with the occupation of similar trophic niches or intraspecific interactions. According to the principle of competitive exclusion, two populations of different species living sympathetically cannot occupy exactly the same ecological niche (Zaret and Rand, 1971; Giacomini, 2007). Under these conditions, and in the presence of a limiting resource, there may be an overlap of niches and one of the populations will be excluded or ecologically displaced (Zaret and Rand, 1971).

In fish communities, from the ecological point of view and from the knowledge that a species feeds, we can obtain information on the trophic relationships that are established in the aquatic ecosystem, including the biological mechanisms of intra and interspecific interactions (Hérran, 1988). However, there is no scientific information detailing aspects of ecology, food and reproductive biology of the species described in this article. Thus, this article aimed to analyze the diets of the species and analyze their possible trophic relationships in nature.

\section{Material and Methods}

Samplings were accomplished in the Amanã Sustainable Development Reserve (ASDR) located between the black water of Negro river and white water of the rivers Japurá and Solimões .Three streams were selected, two with black water (Baré: $02^{\circ} 17^{\prime} \mathrm{S}$ and $64^{\circ} 40^{\prime} \mathrm{W}$ and Juá Grande: 02² 29'S and 64 $48^{\prime}$ W); and one with white water (Kalafate: $02^{\circ} 37^{\prime} \mathrm{S}$ and $64^{\circ} 34^{\prime} \mathrm{W}$ ). Two samplings were carried out one in November 2002 (dry season) and the other in August 2003 (rainy season). Specimens were collected through standardized experimental fishing using hand nets and small trawl nets, in streams with free, shallow environments, in small meanders arranged along the streams' path and along the marginal flooded vegetation (Mendonça et al., 2005).

The collected material was fixed in a solution of $10 \%$ formalin and stored in plastic bags. After washing in running water, the samples were transferred to flasks with $70 \%$ ethanol and stored. For data analysis we used relationships among species only sampling events were considered, where at least two of the three species were captured together, i.e. caught in the same fishing equipment in the same location, date and time.

\subsection{Diet composition}

To determine the composition of the diets, the selected specimens were measured (standard length-SL, millimeters-mm) opened through an incision in the ventral region and the digestive tracts were removed and stored in $70 \%$ alcohol. Thereafter, each stomach was dissected and examined under a stereomicroscope, and the food items were sorted and identified to the most precise taxonomic level possible, following the recommendations of McCafferty (1981), Borror et al. (1981), and Merrit and Cummins (1996).

The degree of stomach repletion of each specimen was evaluated in a proportional scale: 1 . Empty (0\%); 2. Little full (25\%); 3. Frequent (50\%); 4. Full (75\%); 
5. Distended (100\%) (Yabe and Bennemann, 1994). Relative volume (RV) (defined as the percentage in volume of each item in relation to the total food in the stomach) was calculated for each type of food identified and due to small size of the stomachs of the fish, we used petri dishes for the indirect estimation, with the items estimated by visual evaluation, generating comparison with blocks of known volumes (Larimore, 1957; Teixeira and Gurgel, 2002).

Moreover, the frequency of occurrence (FO\%) of ingested items was calculated): $\mathrm{FO} \%=100 \mathrm{x}$ Fi/n, where: $\mathrm{Fi}$ is the number of stomachs containing a particular prey taxon; $\mathrm{n}$ is the total number of stomachs with any prey.

\subsection{Feeding strategies}

The results of both methods were combined in the Feeding Index (IAi, Kawakami and Vazzoler, 1980), expressed as a percentage. This index assesses the degree of importance of each food item in the fish diet, where: $=\mathrm{IAi}=$ feeding index; $\mathrm{i}=1,2, \ldots \mathrm{n}=$ particular food item; $\mathrm{Fi}=\mathrm{FO} \%$ of item $i$; and $\mathrm{Vi} \%=$ volume of item $i$. According to the expression: $\mathrm{IAi}=\mathrm{Fi} \times \mathrm{Vi}(\Sigma \mathrm{ni}=1(\mathrm{Fi} \times \mathrm{Vi}))^{-1}$. Feeding strategies of the species were evaluated using the graphic method of Costello (1990), modified by Amundsen et al. (1996), that infers about feeding ecology through the estimate of the specific abundance of the prey (Pi) and its frequency of occurrence, according to the expression $\mathrm{Pi}=(\mathrm{Si} / \mathrm{Sti}) \mathrm{X} 100$, where $\mathrm{Si}=$ number of stomach containing the prey $i$; Sti = total number of stomachs in which the prey $i$ occurs.

\subsection{Similarity of diets}

Similarity between the diets of Carnegiella marthae, C. strigata and Gnathocharax steindachneri was calculated using the simplified index of Morisita-Horn (Krebs, 1998), applied to combinations of pairs of species (C. marthae and C. strigata; C. marthae and G. steindachneri; C. strigata and G. steindachneri). This index uses the frequency of occurrence of the items ingested by each species. Uses a scale from 0 (zero), indicating absence of the use of the same source (absence of similarity diets) to 1 (one) indicating complete similarity of diets. According to the expression: $\mathrm{CH}=2 \Sigma$ niPijPik $\left(\Sigma \mathrm{niP}^{2} \mathrm{ij}+\Sigma \mathrm{niP}^{2} \mathrm{ik}\right)^{-1}$, where $\mathrm{CH}=$ Simplified Index of overlap between species $\mathrm{j}$ and species $\mathrm{k}$; Pij= proportion of the food $\mathrm{i}$ in the total food of the species $\mathrm{j}$; Pik = proportion of food $\mathrm{i}$ in total food of the species $\mathrm{k} ; \mathrm{n}=$ total number of food $(\mathrm{i}: 1,2,3,4, \ldots, \mathrm{n})$.

\section{Results}

A total number of 943 specimens was caught, being $79.4 \%$ of $C$. marthae (749), collected only in black water. C. strigata represented 3.2\% (30 specimens) and G. steindachneri $17.4 \%$ (164 specimens), collected in both environments, with black and white water. The pattern of occurrence in the region showed the occurrence of the three species in the Baré stream (black water). In Juá Grande (black water) only C. marthae and G. steindachneri were found. In Kalafate stream (white water) C. strigata and $G$. steindachneri were present.

The pattern of occurrence revealed that in the Baré stream (black waters) the three species investigated in the present study occurred. In the Juá Grande stream (black waters), only the species C. marthae and G. steindachneri occurred. In the Kalafate stream, which has clear waters, the species C. strigata and G. steindachneri occurred. The co-occurrence of G. steindachneri and C. marthae, and C. marthae and C. strigata was restricted to the black water environment (Baré stream). The occurrences of the species C. strigata and G. steindachneri together, were restricted to environments of clear water (igarapé Kalafate).

In the Baré stream the co-occurrence of $C$. marthae and C. strigata was observed with 81 specimens caught in the same sample event, at the 3:1 proportion, respectively. For C. marthae and G. steindachneri the proportion observed was 5:1. In Kalafate, the proportion of $C$. strigata and G. steindachneri was approximately $1: 1$ and narrow co-occurrence (i.e., in the same sampling event) was not observed between the species in Juá Grande.

\subsection{Diet composition}

Of the total species captured, only 92 stomachs of the three species were evaluated (32 of C. marthae, 30 of C. strigata and 30 of G. steindachneri) for meeting the criteria for the analysis of co-occurrence patterns (species captured in the same equipment) fishing, location, date and time). Regarding empty stomach, C. marthae presented $68 \%$ (22), C. strigata $41 \%$ (13) and G. steindachneri 3\% (one stomach). Considering the degree of repletion, only C. strigata presented one specimen with full stomach and another with distended stomach.

Thirteen types food items were found in the diet of the three evaluated species, mainly insects as Collembola, Homoptera (nymphs), Lepidoptera (larvae), Ephemenoptera (nymphs), Hemiptera (Gerridae: nymphs + adults), Diptera (larvae + adults); Chironomide (larvae); Chaoboridae (larvae), Coleoptera (adult). Fragments of insects and plants were found in the stomach contents, but the precise identification was not possible due to the advanced stage of digestion. Food items were grouped into the categories of order or family (Table 1 ).

Seven food items were found in the stomachs of C. marthae, in the same frequency: Ephemenoptera (nymph), Diptera (adult + larva), Chironomidae (larva), Coleoptera (adult), fish scales. In the stomachs of $C$. strigata eight food items were verified, plant fragments in higher frequency (31\%), followed by Coleoptera (27\%) and adult Hymenoptera (16\%), this constituted by several species of ants. The most important food items were Coleoptera (46\%) and Hymenoptera (adult) 25\%. Although plant fragments occurred at a higher frequency, its feeding importance was very low (Table 1). G. steindachneri ingested 11 food items (Table 1). The mostly frequent food items were Gerridae (nymph + adult) accounting for $28 \%$ and presenting feeding importance of $48 \%$, followed by Chaoboridae with frequency of occurrence of $20 \%$ and feeding importance $31 \%$. 
Table 1. Frequency of occurrence (FO\%), relative volume (RV), feed rate (IAi) and the specific abundance of prey (AE), expressed as percentages of food items found in the stomachs of studied species ( $n=$ number of stomachs with food, $L=$ larva, $N=$ nymph, $A=$ adult).

\begin{tabular}{|c|c|c|c|c|c|c|c|c|c|c|c|c|}
\hline \multirow{2}{*}{ Food Items } & \multicolumn{4}{|c|}{ C. marthae $(\mathrm{n}=10)$} & \multicolumn{4}{|c|}{ C. strigata $(\mathrm{n}=19)$} & \multicolumn{4}{|c|}{ G. steindachneri $(\mathrm{n}=29)$} \\
\hline & FO\% & RV\% & IAi\% & $\mathrm{AE} \%$ & FO\% & RV\% & IAi\% & AE\% & FO\% & RV\% & IAi\% & AE\% \\
\hline Collembola & & & & & & & & & 2.0 & 1.0 & 1.0 & 1.0 \\
\hline Homoptera (N) & & & & & & & & & 2.0 & 2.0 & 1.0 & 1.0 \\
\hline Lepidoptera (L) & & & & & 4.0 & 2.0 & 1.0 & 6.0 & 2.0 & 2.0 & 1.0 & 1.0 \\
\hline Ephemeroptera (N) & 11.0 & 10.0 & 8.0 & 10.0 & 4.0 & 14.0 & 9.0 & 6.0 & & & & \\
\hline \multicolumn{13}{|l|}{ Hemiptera } \\
\hline Gerridae $(N+A)$ & & & & & 4.0 & 4.0 & 1.0 & 3.0 & 28.0 & 26.0 & 48.0 & 30.0 \\
\hline Hymenoptera (A) & & & & & 16.0 & 21.0 & 25.0 & 29.0 & 9.0 & 8.0 & 5.0 & 4.0 \\
\hline Diptera $(L+A)$ & 11.0 & 10.0 & 17.0 & 10.0 & & & & & 8.0 & 11.0 & 3.0 & 4.0 \\
\hline Chironomidade (L) & 11.0 & 10.0 & 8.0 & 10.0 & 4.0 & 4.0 & 1.0 & 3.0 & & & & \\
\hline Chaoboridae (L) & & & & & & & & & 20.0 & 24.0 & 31.0 & 43.0 \\
\hline Coleoptera (A) & 11.0 & 10.0 & 17.0 & 10.0 & 27.0 & 22.0 & 46.0 & 26.0 & 4.0 & 5.0 & 1.0 & 2.0 \\
\hline Fish scales & 11.0 & 10.0 & 8.0 & 20.0 & & & & & 9.0 & 3.0 & 2.0 & 5.0 \\
\hline Insects fragments & 22.0 & 30.0 & 25.0 & 20.0 & 4.0 & 30.0 & 9.0 & 23.0 & 11.0 & 13.0 & 4.0 & 5.0 \\
\hline Planto of fragments & 22.0 & 20.0 & 17.0 & 20.0 & 31.0 & 4.0 & 8.0 & 3.0 & 4.0 & 4.0 & 3.0 & 2.0 \\
\hline
\end{tabular}

\subsection{Feeding strategies}

The feeding strategies of the species are presented in Figure $1 \mathrm{~A}, \mathrm{~B}$ and C. Small amounts of some food items were observed in stomachs of $C$. marthae, i.e. low specific abundance, and a high rate of empty stomachs. Based on frequency and abundance of the ingested food items, the population of $C$. marthae presented a generalist feeding strategy, with the points representing preys (food items) distributed in the lower left corner of the graph (Figure 1A). The $C$. strigata population presented a generalist feeding strategy, similar to $C$. marthae with low values of occurrence frequency and specific abundance of preys, but with presence of Hymenoptera, Coleoptera and fragments of insects (Figure 1B). G. steindachneri also showed a generalist feeding strategy, with most of the prey points in the lower left corner of the graph (Figure 1C). However, a greater importance of two of the food items was observed, Chaoboridae (L) and Gerridae ( + + A).

\subsection{Similarity of diets}

Diet similarity was calculated for each species. The pairs Carnegiella strigata and G. steindachneri; Carnegiella marthae and $G$. steindachneri presented different diets with $\mathrm{CH}=0.34$ indicating low similarity in feeding behavior. C. strigata and C. marthae showed a much higher similarity index, $\mathrm{CH}=0.61$.

\section{Discussion}

The C. marthae, C. strigata and G. steindachneri feed basically on both terrestrial and aquatic insects. Thus, insects are an important food source for fish populations, especially in the streams of Amazon.

\subsection{Feeding strategies}

We can infer that these studied species are predominantly insectivorous generalists, that is, they belong to the same trophic guild, and still describe that the morphological adaptations of the collected species enabling efficient catches of insects and other items that fall into the surface of streams, resulting in a generalist or opportunistic feeding diet (Abelha et al., 2001). The differences observed in the structure of mouth and teeth of the species indicate the possibility of different origins for insect fragments in the stomach contents (Abelha et al., 2001). On the other hand, cuspidate teeth are efficient for mastication and processing of preys (Langler et al., 1977), which may have generated the fragments of insects found in the stomachs. In contrast, the big mouth and conical teeth of G. steindachneri, usually found in predatory fish (Bemvenuti and Fischer, 2010), could explain the low proportion of fragments of insects in the composition of its diet.

Only one food item was found per stomach of C. marthae, which can indicate a specialized feeding strategy (Abelha et al., 2001). According to the studies of Amundsen et al. (1996) and Bolnick et al. (2003), when the population presents different individuals specialized in different food sources, possibly it presents a high inter-individual phenotypic component (IPC), indicating some individual specialization for the food strategy. The C. marthae and G. steindachneri presented up to three types of food items per stomach, indicating a more opportunistic feeding strategy. This indicates a population with a high intra-individual phenotypic component (IFC), that is, most of the individuals use several types of resources simultaneously (Amundsen et al., 1996; Bolnick et al., 2003).

Some fish scales were found in stomachs of $C$. strigata and G. steindachneri, which may have four possible origins 

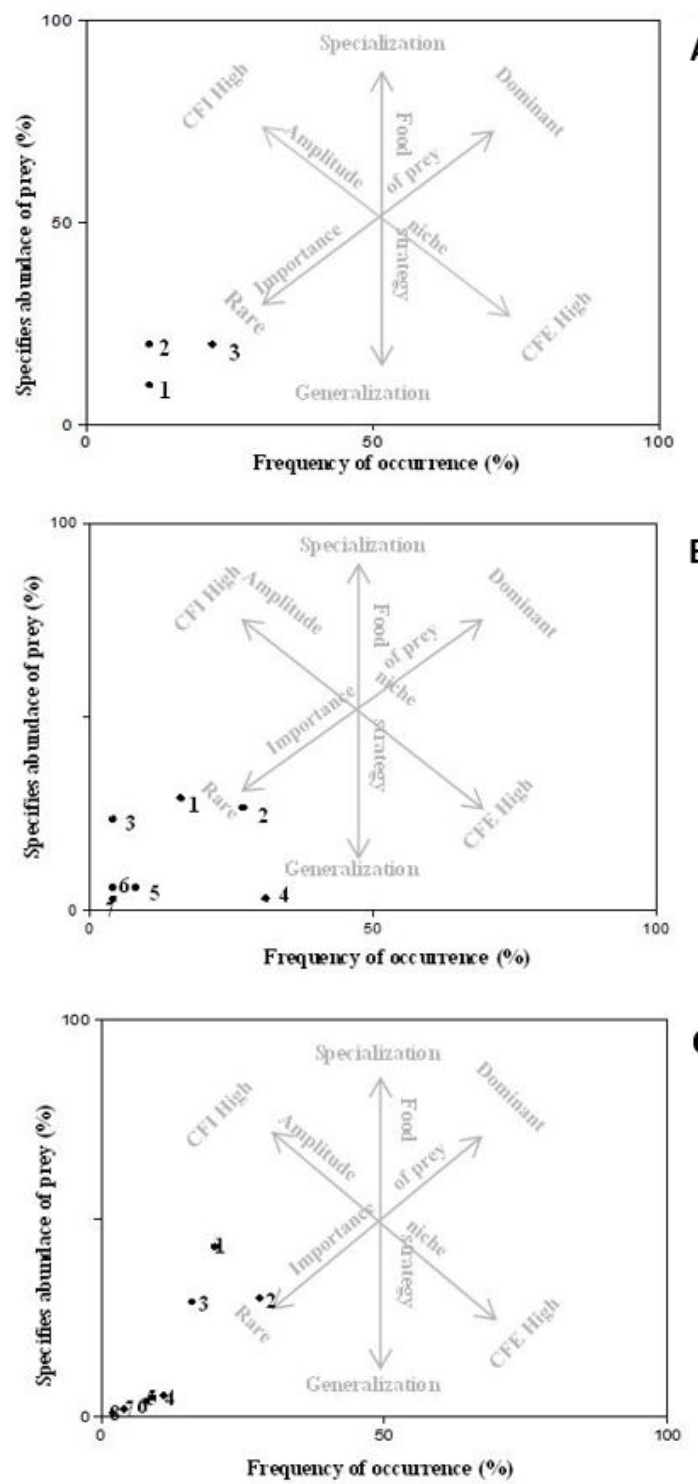

Figure 1. (A) Feed Strategy Carnegiella marthae. (1) Ephemenoptera $(\mathrm{N})$, Diptera (L + A), Chironomidae (L) and Coleoptera (A); (2) Scales of fish; (3) Fragments of plants and insects. Points over an item indicates that they are overlapped; (B) Feed Strategy Carnegiella strigata. (1) Hymenoptera (A); (2) Coleoptera (A); (3) insect fragments; (4) fragments of plants; (5) Ephemenoptera (N); (6) Lepidoptera (L); (7) Chironomidae (L) and Gerridae $(A+L)$. The points-arrested over an item indicates that they are overlapping; (C) Feed Strategy Gnathocharax steindachneri. (1) Chaoboridae (A); (2) Gerridae (N + A); (3) Hymenoptera (A); (4) fragments of insects; (5) fish scales; (6) Diptera (larvae + adults); (7) Coleoptera (A) and vegetable fragments; (8) Collembola, Homoptera (L) and Lepidoptera (L). Points over an item indicates that they are overlapped.

(excluding the possibility of contamination of the samples at the time of removal of the digestive tract for analysis): 1) the scales could be intentionally detached from fish of other species, characterizing a lepidophage behavior;
2 ) the scales could have been removed from conspecifics during agonistic encounters; 3 ) the scales could have been obtained on the environment from various sources; and 4) the scales could be the remains of the digestion of small fish consumed by $C$. marthae and $C$. strigata. The most possible hypothesis is that these scales could have been taken of the environment as they were ingested in small amounts and have very low importance in the diet of the species. Furthermore, these species have no obvious morphological adaptations for lepidophagy, and there are no known published records of aggressive agonistic behavior. Finally, this item should not have been derived from digestion of whole fish, because no fish remains were observed in the stomachs of specimens analyzed (such as bones, muscles).

In the present study, the similarity of diets does not mean complete overlap of trophic niches, probably due to the great diversity of insects available in the environment. Specialized techniques of food capture, for example, can cause segregation of niches and allow the coexistence of the species (Peroni and Hernández, 2011; Chivambo et al., 2019). On the other hand, Motta (1989) reported that teeth morphology and some characteristics of the skull anatomy can indicate a feeding specialization based on the efficiency of exploitation of certain types of food. This author, studying butterfly fish (Chaetodontidae, Perciformes) verified that relatively simple morphological changes in some points of head structure resulted in a diversity of feeding strategies among species. Values of indexes of similarity between C. strigata and G. steindachneri and between $C$. marthae and $G$. steindachneri indicate that was no overlap occurred among these species, which can be due to the high diversity of potential preys available in the Amazon environment, particularly for fish species with opportunistic feeding strategy. A similarity value was observed for C. marthae and C. strigata, indicating that these species could be competing for food.

The Gerridae and Chaoboridae showed a feeding importance in the diet of $G$. steindachneri, but not for the other two species of Carnegiella sp. The high ingestion of insects of the Gerridae family, which live in the water surface of streams, showed the possibility of occurrence of a different form of aggressive mimicry. The gerrids are lurking hunters that feed on carrion and mainly on terrestrial insects that fall on the surface of the streams (Andersen, 1979) and may potentially compete for food with butterfly fish of the genus Carnegiella. Preys that fall in the water surface or remain drifting would be shared by gerrids and butterfly fish, a situation where the morphological adaptations of these fish would be important (powerful fins, mouth facing upwards). It is possible that individuals of $G$. steindachneri take advantage in situations of competition for food between gerrids and butterfly fish in the water surface, and eventually collected together. In this sense, the superficial similarity of form and habits between G. steindachneri and Carnegiella spp. would be sufficient to ensure the effectiveness of the aggressive mimicry involving these species.

The apparent association observed among these species in nature may also represent a case of numerical mimicry, since it is possible to assume the existence of a 
lower individual risk of death by predation for fish that aggregate in shoals. According to the studies of Keenleyside (1979) and Milinski (1993), fish are easier detected by a predator when dispersed (Bozza and Hahn, 2010). Machado (2003), studying fish of the Pantanal, reported the occurrence of numerical mimicry and described that mimic in a multispecies shoal integrates with the largest number of individuals of other species, thereby reducing the risk of predation. In the present study, the occurrence of numerical mimicry may be more probable between G. steindachneri and C. marthae, compared to C. strigata.

\section{Conclusion}

According to the results, we can affirm that the species presented insectivorous eating habits, characterizing dependence in relation to the resources coming from the flooded forest. These species presented a generalist feeding strategy, that is, a wide range of the trophic niche.

Regarding the individual food strategy, only C. Marthae showed a tendency towards specialization, whereas C. Strigata and G. Steindachneri demonstrated a generalist individual food strategy, that is, food based on the opportunistic consumption of items available in the environment.

There was low food overlap between Carnegiella species over Gnathocharax steindachneri, however, among Carnegiellas, the overlap was suggestible which may explain the low frequency of syntopic occurrence between them (possible case of competitive exclusion).

\section{References}

ABELHA, M.C.F., AGOSTINHO, A.A. and GOULART, E., 2001. Plasticidade trófica em peixes de água doce. Acta Scientiarum, vol.23, no. 2, pp. 425-434. https://doi.org/10.4025/actascibiolsci. v23i0.2696.

AMUNDSEN, P.A., GABLER, H.M. and STALDVIK, F.J., 1996. A new approach to graphical analysis of feeding strategy from stomach contents data - modification of the Costello (1990) method. Journal of Fish Biology, vol. 18, pp. 607-614. https://doi.org/10.1111/j.1095-8649.1996.tb01455.x.

ANDERSEN, N.M., 1979. Phylogenetic inference as applied to the study of evolutionary diversification of semiaquatic bugs (Hemiptera: gerromorpha). Systematic Zoology, vol. 28, no. 4, pp. 554-578. http://dx.doi.org/10.2307/2412568.

ANJOS, H.D.B., AMORIM, R.M.S., SIQUEIRA, J.A. and ANJOS, C.R., 2009. Exportação de peixes ornamentais do estado do Amazonas, Bacia Amazônica, Brasil. Boletim do Instituto de Pesca, vol. 35, no. 2, pp. 259-274.

BARROS, D.F., ZUANON, J., MENDONÇA, F. P., ESPIRITO SANTO, H.M.V., GALUCH, A.V. and ALBERNAZ, L.M. 2011. The fish fauna of streams in the Madeira-Purus interfluvial region, Brazilian Amazon. Check List Journal of Species Lists and Distribution, vol. 7, no. 6, pp. 768-773. http://dx.doi.org/10.15560/11022.

BEMVENUTI, M.A. and FISCHER, L.G., 2010. Peixes: morfologia e adaptações. Cadernos de Ecologia Aquática, vol. 5, no. 2, pp. 31-54.

BOLNICK, D.I., SVANBÄCK, R., FORDYCE, J.A., YANG, H., DAVIS, J.M., HULSEY, C.D. and FORISTER, M.L., 2003. The ecology of individuals: incidence and implications of individual specialization. American Naturalist, vol. 161, no. 1, pp. 1-28. http://dx.doi.org/10.1086/343878. PMid:12650459.

BORROR, D.J., DELONG, D.M. and TRIPLEHORN, C.A., 1981. Introdução ao estudo dos insetos. 15. ed. Philadelphia: Saunders College. 928 p.

BOZZA, A.N. and HAHN, N.S., 2010. Uso de recursos alimentares por peixes imaturos e adultos de espécies piscívoras em uma planície de inundação neotropical. Biota Neotropica, vol. 10, no. 3, pp. 217-226. http://dx.doi.org/10.1590/S1676-06032010000300025.

CHAO, N.L., 1998. A draft list of brazilian freshwater fishes for the hobby: a proposal to IBAMA. OFI Journal Issue, vol. 23, pp. 6-14.

CHAO, N.L., 2001. The fishery, diversity, and conservation of ornamental fishes in the Rio Negro Basin, Brasil - A review of project piaba (1989-199). In: N. LABBISH-CHAO. Conservation and management of ornamental fish resources of the rio Negro basin, Amazonia, Brazil - Project Piaba. Manaus: Editora UFAM, pp. 161-204

CHIVAMBO, S., MUSSAGY, A. and BARKI, A., 2019. Assessment of interspecific interactions between the invasive red-claw crayfish (Cherax quadricarinatus) and the Mozambique tilapia (Oreochromis mossambicus). Brazilian Journal of Biology = Revista Brasileira de Biologia, vol. 80, no. 4, pp. 717-726. https://doi.org/10.1590/1519-6984.217868.

COSTELLO, M.J., 1990. Predator feeding and prey importance: a new graphical analysis. Journal of Fish Biology, vol. 36, pp. 261-263. https://doi.org/10.1111/j.1095-8649.1990.tb05601.x.

GIACOMINI, H.C., 2007. Os mecanismos de coexistência de espécies como vistos pela teoria ecológica. Oecologia Brasiliensis, vol. 11, no. 4, pp. 521-543. http://dx.doi.org/10.4257/oeco.2007.1104.05.

HERRÁN, R.A., 1988. Análisis de contenidos estomacales en peces: revisión bibliografica de los objetivos y la metodología. España: Ministerio de Agricultura, Pesca y Alimentación/Secretaría General Técnica. 74 p. Informe tecnico Instituto Español de Oceonografia, no. 63.

KAWAKAMI, E. and VAZZOLER, G., 1980. Método gráfico e estimativa de índice alimentar aplicado no estudo da alimentação de peixes. Boletim do Instituto Oceanográfico, vol. 29, no. 2, pp. 205-207. http://dx.doi.org/10.1590/S0373-55241980000200043.

KEENLEYSIDE, M.H.A., 1979. Diversity and adaptation in fish behaviour. New York: Springer Editora. http://dx.doi. org/10.1007/978-3-642-81374-0.

KREBS, C.J., 1998. Ecological methodology. $2^{\text {nd }}$ ed. California, Menlo Park: Benjamin Cummings. $620 \mathrm{p}$.

LADISLAU, D.S., RIBEIRO, M.W.S., CASTRO, P.D.S., ARIDE, P.H.R., PAIZA, A.J.V., POLESE, M.F., SOUZA, A.B., BASSUL, L.A., LAVANDER, H.D. and OLIVEIRA, A.T., 2019. Ornamental fishing in the region of Barcelos, Amazonas: socioeconomic discription and scenario of activity in the view of "piabeiros". Brazilian Journal of Biology = Revista Brasileira de Biologia, vol. 80, no. 3, pp. 544-556. http://doi.org/10.1590/1519-6984.215806.

LANGLER, K., BARDACH, J., MILLER, R.R. and PASSINO, D.R.M., 1977. Ichthyology. 2th ed. New York: John Wiley \& Sons, Inc. 506 p.

LARIMORE, W.R., 1957. Ecological life history of the warmouth (Centrarchidae). Bulletin - Illinois Natural History Survey, vol. 27, no. 1-6, pp. 81-82. http://dx.doi.org/10.21900/j.inhs.v27.170.

MACHADO, F.A., 2003. História natural de peixes do Pantanal: com destaque em hábitos alimentares e defesa contra predadores. Campinas: Universidade Estadual de Campinas. 99 p. Tese de doutorado em Ecologia.

MCCAFFERTY, W.P., 1981. Aquatic entomology: the fishermen's and ecologists' Illustrated guide to insects and their relatives. Boston: Jones and Bartllet Publishers, INC. 201 p. 
MENDONÇA, F.P., MAGNUSSON, W.E. and ZUANON, J., 2005. Relationships between habitat characteristics and fish assemblages in small streams of Central Amazonia. Copeia, vol. 4, no. 4, pp. 751-764. http://dx.doi.org/10.1643/00458511(2005)005[0751:RBHCAF]2.0.CO;2.

MENEGATTI, J.V., VESCOVI, D.L. and FLOETER, R.S., 2003. Interações agonísticas e forrageamento do peixe-donzela, Stegastes fuscus (Peciformes: Pomacentridae). Natureza on line, vol. 1, no. 2, pp. 45-50.

MERRIT, R.W. and CUMMINS, K.W., 1996. A introduction to the aquatic insects of North America. 3rd ed. Dubuque: Hunt Publishing. $82 \mathrm{p}$.

MILINSKI, M., 1993. Predation risk and feeding behaviour. In: T.J. PITCHER, ed. Behaviour of teleost fishes. 2nd ed. London: Chapman \& Hall. 715 p. http://dx.doi.org/10.1007/978-94-011-1578-0_9.

MISE, F.T., FUGI, R., PAGOTTO, J.P.A. and GOULART, E., 2013. The coexistence of endemic species of Astyanax (Teleostei: Characidae) is propitiated by ecomorphological and trophic variations. Biota Neotropica, vol. 13, no. 3, pp. 21-28. http://dx.doi.org/10.1590/S1676-06032013000300001.

MONTAG, L.F.A., FREITAS, T.M.S., WOSIACKI, W.B. and BARTHEM, R.B., 2008. Os peixes da Floresta Nacional de Caxiuanã (municípios de Melgaço e Portel, Pará - Brasil). Bol. Mus. Emílio Goeldi Ciências Naturais, vol. 3, no. 1, pp. 11-34.

MOTTA, P.J., 1989. Dentition patterns among Pacific and Western Atlantic butterflyfishes (Perciformes, Chaetodontidae): relationship to feeding ecology and evolutionary history. Environmental Biology of Fishes, vol. 25, no. 159, pp. 159-170. http://dx.doi.org/10.1007/BF00002209.

NOVAKOWSKI, G.C., HAHN, N.S. and FUGI, R., 2007. Alimentação de peixes piscívoros antes e após a formação do reservatório de Salto Caxias, Paraná, Brasil. Biota Neotropica, vol. 7, no. 2, pp. 149-154. http://dx.doi.org/10.1590/S1676-06032007000200017.

OLIVEIRA, E., IGNÁCIO, A.R.A., LÁZARO, W.L., MUNIZ, C.C., CAMPOS, D.V.S., COSTA, J.V.M., RIBEIRO,T. and SANTOS-FILHOS, M., 2020. Feeding aspects of Knodus heteresthes (Eigenmann, 1908) and Moenkausia lepidura (Kner, 1858) (Characiformes, Characidae) in the Teles Pires and Juruena Rivers, southern Amazon. Brazilian Journal of Biology = Revista Brasileira de Biologia, In press. https;//doi.org/10.1590/1519-6984.226136.

PACHECO, E.B. and DA-SILVA, C.J., 2009. Fish associated with aquatic macrophytes in the Chacororé-Sinhá Mariana Lake system and Mutum River, Pantanal of Mato Grosso, Brazil. Brazilian Journal of Biology = Revista Brasileira de Biologia, vol. 69, no. 1, pp. 101-108. http://dx.doi.org/10.1590/S151969842009000100012. PMid:19347151.

PEREIRA, P.H.C., FEITOSA, J.L.L. and FERREIRA, B.P., 2011. Mixedspecies schooling behavior and protective mimicry involving coral reef fish from the genus Haemulon (Haemulidae). Neotropical Ichthyology, vol. 9, no. 4, pp. 741-746. http://dx.doi.org/10.1590/S1679-62252011005000037.

PERONI, N. and HERNÁNDEZ, M.I.M., 2011. Ecologia de populações e comunidades. Florianópolis: CCB/EAD/UFSC. 123 p.

QUEIROZ, L.J., TORRENTE-VILARA, G., OHARA, W.M., PIRES, T.H.S., ZUANON, J. and DORIA, C.R.C., 2013. Peixes do Rio Madeira: Y-Cuyari Pirá-Ketá. Manaus: INPA/UFAM, vol. 1, pp. 206-211.

SABINO, J. and ZUANON, J., 1998. A stream fish asemblage in Central amazonia: distribuition, activity patterns and feeding behavior. Ichthyological Exploration of Freshwaters, vol. 8, no. 3, pp. 201-210.

SAZIMA, I., KRAJEWSKI, J.P., BONALDO, R.M. and SAZIMA, C., 2005. Wolf in a sheep's clothes: juvenile coney (Cephalopholis fulva) as an aggressive mimic of the brown chromis (Chromis multilineata). Neotropical Ichthyology, vol. 3, no. 2, pp. 315318. http://dx.doi.org/10.1590/S1679-62252005000200011.

TEIXEIRA, J.L.A. and GURGEL, H.C.B., 2002. Métodos de análise do conteúdo estomacal em peixes e suas aplicações. Arquivos do Mudi, vol. 6, no. 1, pp. 20-25.

WEITZMAN, S.H. and PALMER, L., 1996. Do freshwater hatchet fishes really fly? Tropical Fish Hobbyist, vol. 45, no. 1, pp. 195-206.

WEITZMAN, S.H. and PALMER, L., 2003. Family gasteropelecidae (Freshwater hatchetfishes). In: R.E. REIS, S.O. KULLANDER and C.J. FERRARIS JUNIOR, eds. Check list of the freshwater fishes of South and Central America. Porto Alegre: EDIPUCRS, pp. 101-103.

WIEST, F.C., 1995. The specialized locomotory apparatus of the freshwater hatchetfish family Gasteropelecidae. Journal of Zoology (London, England), vol. 236, no. 4, pp. 571-592. http://dx.doi.org/10.1111/j.1469-7998.1995.tb02733.x.

YABE, R.S. and BENNEMANN, T., 1994. Regime alimentar de Schizodon intermedius (Garavello \& Britski) do rio Tibagi, Paraná, e sua relação com algumas características morfológicas do trato digestivo (Osteichthyes, Anostomidae). Revista Brasileira de Zoologia, vol. 11, no. 4, pp. 777-788. http://dx.doi.org/10.1590/ S0101-81751994000400019.

ZARET, T. M. and RAND, A. S., 1971. Competition in tropical stream fishes: support for the competitive exclusion principle. Ecology, vol. 2, no. 52, pp. 336-342. https://doi.org/10.2307/1934593. 